\section{The international response of primary health care to COVID-19: document analysis in selected countries}
A resposta internacional da atenção primária em saúde à COVID-19: uma análise documental em países selecionados

\section{La respuesta internacional de la atención primaria en salud a la COVID-19: análisis de documentación en países seleccionados}

Nilia Maria de Brito Lima Prado 1

Thais Regis Aranha Rossi 2

Sônia Cristina Lima Chaves 3

Sandra Garrido de Barros 3

Laio Magno 2

Hebert Luan Pereira Campos dos Santos 1

Adriano Maia dos Santos 1

\begin{abstract}
This study examines the primary health care (PHC) organization in response to the COVID-19 epidemic. This is a descriptive study based on the document analysis of the countries' responses to the coronavirus pandemic with emphasis on PHC. In various countries, there have been different organizations and impacts of strategies since they have conducted actions according to the local characteristics of disease transmission, demography, public health services organization, and health system's capacity and financing, especially in the PHC area. A significant change during the pandemic has been the increase in telephone and video consultations incorporating health information technology. An efficient PHC, guided by essential actions, achieves more suitable results. Also, each country's cumulative capacity or experience makes the difference facing the emerging demands on different health systems.
\end{abstract}

Primary Health Care; Coronavirus Infections; Health Policy; Health Systems

\author{
Correspondence \\ N. M. B. L. Prado \\ Instituto Multidisciplinar em Saúde, Universidade Federal \\ da Bahia. \\ Rua Hormínio Barros 58, Vitória da Conquista, BA \\ 45029-094, Brasil. \\ nilia.ufba@gmail.com \\ 1 Instituto Multidisciplinar em Saúde, Universidade Federal da \\ Bahia, Vitória da Conquista, Brasil. \\ 2 Departamento de Ciências da Vida, Universidade do Estado da \\ Bahia, Salvador, Brasil. \\ 3 Faculdade de Odontologia, Universidade Federal da Bahia, \\ Salvador, Brasil.
}




\section{Background}

Primary health care (PHC) is globally considered the basis for a sustainable and competent health system to cope with the most frequent community health problems and challenges and to promote equity 1,2 . There is a consensus that the PHC is the most effective and resolutive healthcare model. However, there are diverse interpretations and conceptions in implementing health policies around the world $3,4,5$.

Along with the challenges concerning the PHC organization in global health systems, the severe acute respiratory syndrome pandemic caused by SARS-CoV-2 (COVID-19) has exposed this century's challenges on a global scale concerning insufficient scientific knowledge about the novel coronavirus 6,7 . The rapid spread of the virus has been worrisome ${ }^{6}$, as well as the potential to cause deaths in vulnerable populations ${ }^{8}$, and uncertainties regarding the best strategies to face the epidemic in several countries 9 .

Given this scenario, the PHC importance in addressing this pandemic is highlighted, since studies have shown that about $80 \%$ of the disease cases are mild, and most moderate cases seek PHC services as a gateway to medical care $7,10,11$.

The current COVID-19 pandemic situation reinforces the need for States' policies and responses to include comprehensive PHC in many developing countries with fragmented/segmented health systems, high social inequality, and limited investment in the healthcare sector 12. In this scenario, some countries have adopted innovative strategies for planning and organizing PHC in order to ensure care continuity flow at all levels: meeting new demands, managing risks, and promoting care coordination $13,14,15,16$.

In this context, PHC needs to be strengthen in order to face COVID-19. In this sense, it is fundamental to analyze the scope and impact of the strategies that the PHC adopts in several countries and in different ongoing contexts to support reflections about the lessons and gaps for the system and service organizations in public health emergencies.

Therefore, this study examined the PHC system organizations in response to the COVID-19 epidemic, identifying its dimensions and possible substantial variations in countries and the responses of the primary health care system. Synthesizing the available evidence on the interventions carried out by the different countries can contribute to the planning and implementation of faster and more resolute actions and base decision making regarding the choice of appropriate strategies by the health professionals and managers in their daily work.

\section{Methods}

This is a descriptive study based on the document analysis of the countries' responses to the coronavirus pandemic with emphasis on PHC. We considered protocols, official documents, and publications on government websites as the State response.

We gathered and analyzed existing technical evidence on PHC capacity responses by countries most affected by the coronavirus pandemic. Therefore, it was considered as a strong primary care the ones characterized by a first level assistance with the capacity to solve most health problems in a timely manner, with accessibility and guarantee of continuity and other attributes. The responsiveness is defined as the capacity of the primary care unit to provide care that meets users' health expectations of dignity, privacy, promptness, and quality 17,18 .

The data production involved the document search on the fight against COVID-19, regarding PHC, in April and May 2020 from the official websites of the sanitary services from the health systems of the countries considered for this research. We saved each document or publication in PDF format. We also consulted the database of the World Health Organization - WHO (https://covid19.who. int/) and Our World in Data (https://ourworldindata.org/). We considered the data on May 11, 2020, for analysis.

The following countries were included in this study according to the criteria (Table 1): (a) China (a country that notified the first SARS-CoV-2 case to the WHO and has already deliberated the return to 
Table 1

Indicators * related to the national response to coronavirus by countries included in the document review 25.

\begin{tabular}{|c|c|c|c|c|c|c|c|}
\hline Country & $\begin{array}{l}\text { Did the testing } \\
\text { involve PHC? }\end{array}$ & $\begin{array}{l}\text { Date of the } \\
\text { first case }\end{array}$ & $\begin{array}{c}\text { Deaths by COVID-19/ } \\
\text { Confirmed cases * }\end{array}$ & Lethality (\%) & $\begin{array}{l}\text { Population/ } \\
\text { Population density }\end{array}$ & $\begin{array}{c}\text { Extreme poverty } \\
(2010)(\%)\end{array}$ & HDI \\
\hline China & Yes & 31/Dec/2019 & $4,637 / 84,010$ & 5.19 & $1,439,323,774$ & NA & 0.727 \\
\hline United States & No & 21/Jan/2020 & $79,528 / 1,329,799$ & 5.98 & $331,002,647 / 35.60$ & 1.2 & 0.915 \\
\hline Singapore & Yes & 24/Jan/2020 & $20 / 23,336$ & 0.08 & $5,850,343 / 7,915.70$ & NA & 0.912 \\
\hline Australia & Yes & 25/Jan/2020 & $97 / 6,491$ & 1.49 & $25,499,881 / 3.20$ & 0.5 & 0.935 \\
\hline France & No & 25/Jan/2020 & $26,380 / 139,063$ & 18.97 & $65,273,512$ & NA & 0.888 \\
\hline Canada & Yes & 26/Jan/2020 & 4,871/68,848 & 7.07 & $37,742,157 / 4.01$ & 0.5 & 0.913 \\
\hline Germany & Yes & 28/Jan/2020 & $7,417 / 169,575$ & 4.37 & $83,783,945 / 237.00$ & NA & 0.916 \\
\hline Italy & No & 31/Jan/2020 & $30,560 / 219,070$ & 13.95 & $60,461,828 / 205.86$ & 2.0 & 0.873 \\
\hline United Kingdom & No & 31/Jan/2020 & $31,855 / 219,183$ & 14.53 & $67,886,004 / 272.89$ & 0.2 & 0.907 \\
\hline Spain & No & 01/Feb/2020 & $491 / 11,178$ & 4.39 & $46,754,783 / 93.10$ & 1.0 & 0.876 \\
\hline Portugal & No & 03/Feb/2020 & $1,135 / 27,581$ & 4.12 & $10,196,707 / 112.37$ & 0.5 & 0.830 \\
\hline Iran & No & 20/Feb/2020 & $6,640 / 107,603$ & 6.17 & $83,992,953 / 49.83$ & 0.2 & 0.766 \\
\hline Brazil & No & 26/Feb/2020 & $11,123 / 162,699$ & 6.83 & $212,559,409 / 25.04$ & 3.4 & 0.755 \\
\hline New Zealand & Yes & 28/Feb/2020 & $21 / 1,147$ & 1.83 & $4,822,233 / 18.20$ & NA & 0.913 \\
\hline Iceland & No & 29/Feb/2020 & $10 / 1,801$ & 0.55 & 341,250 & 0.2 & 0.899 \\
\hline
\end{tabular}

HDI: Human Development Index; NA: not available; PHC: primary health care.

Source: World Health Organization (https://covid19.who.int/) and Our World in Data (https://ourworldindata.org/); accessed on 11/May/2020.

* Updated until May 11, 2020.

social activities, considering the reduction of cases); (b) Germany, Brazil, United States, Spain, France, Iran, Italy, and United Kingdom (the eight countries with the highest number of cases reported by WHO); (c) Australia, Canada, Iceland, Portugal, Singapore, and New Zealand (countries with extensive testing for COVID-19, including in asymptomatic patients, which have flatten the curve of the epidemic.

We stratified the responses of countries according to the date of the first case and the organizational characteristics of health systems and PHC. The evidence derived from policies and action plans in relation to the $\mathrm{PHC}$ response capacity.

The websites in Portuguese, English, Spanish, and French were read in the original language. Those in German and Chinese were translated into English using the Google Translate tool (https:// translate.google.com/). After searching, the 35 selected documents (Box 1) were read in their entirety and the following aspects were systematized: title, authorship and year of publication, country of origin, the title of the document, specific policies, strategies in the containment and mitigation phase, strategies for PHC reorganization.

The document research involved three stages: (i) organization, (ii) pre-analysis, and (iii) material analysis. The exploratory phase required reading the documents and classifying them according to dimensions and theoretical/analytical categories. Two of the researchers-authors conducted the content analysis of the selected documents.

The strategy of classification and analysis for the PHC reorganization attended the following categories: (i) response capacity of reorganizing and strengthening the first level of care; (ii) recruitment and training of human resources in health; (iii) integration between outpatient services and social equipment in the territory; (iv) implementation of healthcare technology strategies. Issues related to each country's epidemic curve were also analyzed (date of the first case, number of confirmed cases, number of deaths, fatality rate), the response of the state concerning testing (characteristic of the testing strategy implemented and the total number of tests), the country's population, population density, percentage of the population over 70 and the Human Development Index (HDI) (Table 1), only to 
Box 1

Systematization of the documents analyzed in each selected country, 2020.

\begin{tabular}{|c|c|}
\hline COUNTRY & DOCUMENTS \\
\hline China & $\begin{array}{l}\text { - Together, we fight the virus! (https://www.coronavirus.gov.hk/eng/) } \\
\text { - Almost } 4 \text { million primary care professionals are participating in the prevention and control of the epidemic outbreak } \\
\text { (https://www.sohu.com/a/373774455_374886) } \\
\text { - Contributions and challenges of general practitioners in china fighting against the novel coronavirus crisis (https://www.ncbi.nlm. } \\
\text { nih.gov/pmc/articles/pmc7103835/) } \\
\text { - Diagnosis \& treatment protocol for COVID-19: discharge (http://english.www.gov.cn/policies/infographics/202004/05/content_ } \\
\text { WS5e894d2cc6d0c201c2cc0359.html) } \\
\text { - Shanghai epidemic prevention and release of control (http://www.chinacdc.cn/en/) } \\
\text { - Timeline of China's fight against the novel coronavirus (http://en.nhc.gov.cn/2020-03/20/c_78021.htm) }\end{array}$ \\
\hline $\begin{array}{l}\text { United } \\
\text { States }\end{array}$ & $\begin{array}{l}\text { - Updates from USA Health on COVID-19 (https://www.usahealthsystem.com/covid-19) } \\
\text { - Implementation of mitigation strategies for communities with local COVID-19 transmission (https://www.cdc.gov/ } \\
\text { coronavirus/2019-ncov/downloads/community-mitigation-strategy.pdf) } \\
\text { - AAFP, others warn Azar about the imminent closure of primary care (https://www.aafp.org/news/government- } \\
\text { medicine/20200522closurewarning.html) } \\
\text { - Primary care and COVID-19: week } 2 \text { survey (https://www.pcpcc.org/2020/03/26/primary-care-covid-19-week-2-survey) } \\
\text { - Primary care and the COVID-19 pandemic (https://www.commonwealthfund.org/blog/2020/primary-care-and-covid-19-pandemic) } \\
\text { - Coronavirus and the US health system: the impact of COVID-19 on primary care and outpatient services (https://www.common } \\
\text { wealthfund.org/press- release/2020/coronavirus-and-us-health-system-impact-covid-19-primary-care-and-outpatient) }\end{array}$ \\
\hline Singapore & $\begin{array}{l}\text { - COVID-19 risk factors among healthcare professionals: a quick review (https://www.sciencedirect.com/science/article/pii/ } \\
\text { S2093791120302961) } \\
\text { - COVID-19: frontline notes, singapore primary health care perspective (https://www.annfammed.org/content/18/3/259.abstract) }\end{array}$ \\
\hline Australia & $\begin{array}{l}\text { - COVID-19: whole of population telehealth for patients, general practice, primary care and other medical services } \\
\text { (https://www.health.gov.au/ministers/the-hon-greg-hunt-mp/media/covid-19-whole-of-population-telehealth-for-patients-general- } \\
\text { practice-primary-care-and-other-medical-services) }\end{array}$ \\
\hline France & $\begin{array}{l}\text { - COVID-19 - tools for healthcare professionals (https://www.santepubliquefrance.fr/maladies-et-traumatismes/maladies-et- } \\
\text { infections-respiratoires/infection-a-coronavirus/articles/infection-au-nouveau-coronavirus-sars-cov-2-covid-19-france-et-monde) } \\
\text { - COVID-19 - France (https://www.santepubliquefrance.fr/publications) }\end{array}$ \\
\hline Canada & $\begin{array}{l}\text { - Interim national surveillance guidelines for human infection with coronavirus disease (COVID-19) (https://www.canada.ca/en/ } \\
\text { public-health/services/diseases/2019-novel-coronavirus-infection/health-professionals/interim-guidance-surveillance-human- } \\
\text { infection.html) } \\
\text { - Interim guidance cases contacts with coronavirus disease (COVID-19) (https://www.canada.ca/en/public-health/services/ } \\
\text { diseases/2019-novel-coronavirus-infection/health-professionals/interim-guidance-cases-contacts.html) } \\
\text { - COVID-19 guidance: acute care (http://www.health.gov.on.ca/en/pro/programs/publichealth/coronavirus/docs/2019_acute_care_ } \\
\text { guidance.pdf) } \\
\text { - Government documents reveal slow start for Canada's COVID-19 response (https://www.cbc.ca/news/politics/covid-19- } \\
\text { government-documents-1.5528726) } \\
\text { - COVID-19 guidance: home and community care providers (http://www.health.gov.on.ca/en/pro/programs/publichealth/ } \\
\text { coronavirus/docs/2019_home_community_care_guidance.pdf) }\end{array}$ \\
\hline Germany & $\begin{array}{l}\text { - Coronavirus disease (COVID-19): observations and lessons from primary medical care at a German community hospital } \\
\text { (https://www.tandfonline.com/doi/full/10.1080/20009666.2020.1763079) } \\
\text { - How high and long will the COVID-19 wave be? A data-driven approach to model and predict the COVID-19 epidemic and the } \\
\text { required capacity for the German health system (https://www.medrxiv.org/content/10.1101/2020.04.14.20064790v1) }\end{array}$ \\
\hline Italy & $\begin{array}{l}\text { - Coronavirus emergency: the national response (http://www.protezionecivile.it/attivita-rischi/rischio-sanitario/emergenze/ } \\
\text { coronavirus/.acc1) } \\
\text { - COVID-19 integrated surveillance: the main national data (https://www.epicentro.iss.it/coronavirus/sars-cov-2-sorveglianza-dati) } \\
\text { - Resources for operators (health and support) of social assistance and health structures (https://www.epicentro.iss.it/coronavirus/ } \\
\text { sars-cov-2-ipc-strutture-socio-assistenziali-sanitarie) }\end{array}$ \\
\hline
\end{tabular}

(continues) 
Box 1 (continued)

\begin{tabular}{|c|c|}
\hline COUNTRY & DOCUMENTS \\
\hline $\begin{array}{l}\text { United } \\
\text { Kingdom }\end{array}$ & $\begin{array}{l}\text { - Primary attention (https://www.england.nhs.uk/coronavirus/primary-care/) } \\
\text { - Guidance and standard operating procedures coronavirus (COVID-19) and general practice (https://www.england.nhs.uk/ } \\
\text { coronavirus/wp-content/uploads/sites/52/2020/03/managing-coronavirus-covid-19-in-general-practice-gp-sop_19-march.pdf) } \\
\text { - Procurement of pre-approved suppliers of online and video consultation systems for GP practices to support COVID-19 } \\
\text { (https://www.england.nhs.uk/coronavirus/wp-content/uploads/sites/52/2020/03/C0079-Suppliers-of-online-and- } \\
\text { video-consultations.pdf) } \\
\text { - Tell the NHS about your current experience of coronavirus (https://healthwatchgateshead.co.uk/news/tell-the-nhs-about-your- } \\
\text { current-experience-of-coronavirus/) } \\
\text { - Check if you or your child has coronavirus symptoms (https://www.nhs.uk/conditions/coronavirus-covid-19/check-if-you-have- } \\
\text { coronavirus-symptoms/) } \\
\text { - Novel coronavirus (COVID-19) standard operating procedure (https://www.england.nhs.uk/coronavirus/wp-content/uploads/ } \\
\text { sites/52/2020/03/C0659-covid-19-community-pharmacy-sop-v3-aug.pdf) }\end{array}$ \\
\hline Spain & $\begin{array}{l}\text { - Management of COVID-19 in primary care and home care (https://www.mscbs.gob.es/en/profesionales/saludPublica/ccayes/ } \\
\text { alertasActual/nCov-China/documentos/Manejo_primaria.pdf) } \\
\text { - Assessment of the declaration of the } 2019 \text { new coronavirus outbreak (n-CoV) a Public Health Emergency of International Importance } \\
\text { (ESPII) (https://www.mscbs.gob.es/en/profesionales/saludPublica/ccayes/alertasActual/nCov/documentos/Valoracion_declaracion_ } \\
\text { emergencia_OMS_2019_nCoV.pdf) } \\
\text { - Guide for using rapid antibody tests for COVID-19 (https://www.lamoncloa.gob.es/lang/en/gobierno/news/ } \\
\text { paginas/2020/20200407covid19-tests.aspx) } \\
\text { - Strategy for early detection, surveillance and COVID-19 control (https://www.mscbs.gob.es/profesionales/saludpublica/ccayes/ } \\
\text { alertasactual/ncov/documentos/covid19_estrategia_vigilancia_y_control_e_indicadores.pdf) }\end{array}$ \\
\hline Portugal & $\begin{array}{l}\text { - Rule n. 003/2020 from 19/Mar/2020 updated 22/Mar/2020 (https://www.dgs.pt/directrizes-da-dgs/normas-e-circulares-normativas/ } \\
\text { norma-n-0032020-de-19032020.aspx) }\end{array}$ \\
\hline Iran & $\begin{array}{l}\text { - Coronavirus disease } 2019 \text { in Iran: the need for more attention to primary health care (https://www.ncbi.nlm.nih.gov/pmc/ } \\
\text { articles/PMC7181995/) }\end{array}$ \\
\hline Brazil & $\begin{array}{l}\text { - Clinical management protocol for coronavirus (COVID-19) in primary health care (https://saude.rs.gov.br/upload/ } \\
\text { arquivos/202004/14140606-4-ms-protocolomanejo-aps-ver07abril.pdf) } \\
\text { - Clinical management protocol (http://189.28.128.100/dab/docs/portaldab/documentos//solamento_domiciliar_populacao_ } \\
\text { APS_20200319_ver001.pdf) } \\
\text { - General guidance on the role of the CHW in the face of the COVID-19 pandemic (http://189.28.128.100/dab/docs/portaldab/ } \\
\text { documentos/20200403_recomendacoes_ACS_COVID19_ver002_final_b.pdf) } \\
\text { - General guidelines for the COVID-19 pandemic (http://189.28.128.100/dab/docs/portaldab/documentos/esus/Orientacoes_ACS_ } \\
\text { COVID_19.pdf) } \\
\text { - How to register in e-SUS PHC when a teleconsultation is performed (http://189.28.128.100/dab/docs/portaldab/documentos/esus/ } \\
\text { COMO_REGISTRAR_NO_e_SUS_APS_TELECONSULTA.pdf) }\end{array}$ \\
\hline $\begin{array}{l}\text { New } \\
\text { Zealand }\end{array}$ & $\begin{array}{l}\text { - COVID-19: Primary care quick reference guide (https://www.health.govt.nz/system/files/documents/pages/covid-19-primary-care- } \\
\text { quick-reference-guide-19-april-2020.pdf) } \\
\text { - Telehealth (https://www.health.govt.nz/our-work/digital-health/other-digital-health-initiatives/telehealth) } \\
\text { - New rules for electronic prescriptions to support virtual care in the community (https://www.health.govt.nz/system/files/ } \\
\text { documents/pages/covid-19-new_rules_for_electronic_prescriptions-3apr20.pdf) }\end{array}$ \\
\hline Iceland & $\begin{array}{l}\text { - Iceland's response (https://www.covid.is/categories/icelands-response) } \\
\text { - Overcoming the odds with systematic individualized care: prospective follow-up across the country for all COVID-19 patients in } \\
\text { Iceland (https://onlinelibrary.wiley.com/doi/full/10.1111/joim.13135) } \\
\text { - Q and A on measures in response to COVID-19 (https://covid.hi.is/spa30-april-2020/) }\end{array}$ \\
\hline
\end{tabular}

Source: prepared by the authors. 
guide the organization of the countries' responses. The data included in Microsoft Excel software (https://products.office.com/) which, after the analysis, originated the summary tables of this study $19,20,21,22$.

\section{Results}

COVID-19 pandemic imposed an enormous impact on health systems in all countries and required rapid responses to meet the demands of the sanitation crisis. Countries adopted different policies to reorganize and strengthen the response capacity of the first level of care and ensure the continuity of actions directed to other health care needs of the population. Besides these services, the care flows started virtual care through telemedicine, which includes telemonitoring people with COVID-19 suspicion, remote surveillance of the symptomatic people's clinical picture, psychological telesupport regarding discomfort and isolation limitations for symptomatic people.

Thus, in order to seek to understand PHC from a systemic perspective in the process of coping with COVID-19, it was necessary to understand what the health care models prioritized in each health system in the countries analyzed (Box 2).

For the analysis of the responses of the states, the distinct ways of organizing health systems were also considered, such as market orientation (United States), social insurance (Germany, France, Canada), and social democracy (United Kingdom, Brazil, Iceland) (Box 2). The PHC organization is also diverse among the 15 countries under study primarily affected by the pandemic. In most cases, they declare PHC as the preferred gateway and filter for specialized care from general practitioners (GPs). In other countries, there is a multi-professional approach (Box 2).

The (re)organization of PHC services focused on intervention axes to adapt to the pandemic, the development of community actions and health surveillance to block and reduce the risk of spreading the epidemic; the continuity of its own actions in its routine of health promotion, disease prevention and provision of care to the population and the participation and social involvement in adhering to health guidelines for mitigating the disease (Box 2). However, significant differences were observed in terms of PHC response capacity.

In China, where the epidemic began, the first case occurred on December 31, 2019. By January 29,2020 , the virus spread to all provinces of its mainland. They organized the response in PHC from the practices of GPs with health education work and joint action with local committees in the neighborhoods and active surveillance of confirmed cases by community police, (daily monitoring of health status and psychological support for individuals under quarantine). Committees for health triage, contact tracing, and investigation of infection sources were also created (Box 2). These networks led by GPs have contributed significantly to data collection and epidemiological studies to prevent disease transmission. GPs used instant messaging tools for community transmissions and electronic dashboards to disseminate information and mobilize residents and volunteers, make prescriptions available online, and act directly at specialized outpatient centers. Professionals monitored the patient's health, managing their existing morbidities, as well as supporting the families of patients and neighbors, making referrals for assistance in hospitals, only when problems could not be resolved in the PHC unit.

In the United States, health care is private and decentralized, with independent providers and many payers. The government funds health insurance only for those over age 65 and for families and individuals with low income and limited resources. On February 25, 2020, when the Centers for Disease Control and Prevention (CDC) confirmed several cases of coronavirus in the United States, even insured users found it difficult to access primary care due to a combination of policies with limited coverage and state restrictions on practice across states borders. An expansion occurred only for the coverage of phone or video calls between doctors and the elderly in rural areas, extended to all those insured by the program. Technical problems, such as limited testing and low health insurance coverage, contributed to the spread of COVID-19 in the United States. Among those with health plans, coverage is often limited and requires a high percentage of co-payment.

Singapore is known to have promptly instituted aggressive restraint and public health measures. A fundamental pillar to support this is the response of the PHC network in private general practice 
Box 2

Health systems general characteristics, primary health care (PHC) organization and response to COVID-19.

\begin{tabular}{|c|c|c|c|}
\hline COUNTRY & $\begin{array}{c}\text { HEALTHCARE SYSTEM, PHC } \\
\text { ORGANIZATION AND TEAM } \\
\text { COMPOSITION }\end{array}$ & SERVICES AVAILABLE AT PHC & $\begin{array}{l}\text { FIRST LEVEL RESPONSE TO THE } \\
\text { COVID-19 EPIDEMIC }\end{array}$ \\
\hline China & $\begin{array}{l}\text { Mixed coverage, public and private. } \\
\text { Every citizen has the right to receive } \\
\text { basic health services provided by local } \\
\text { governments. Mainly village doctors } \\
\text { and health professionals in rural clinics, } \\
\text { GPs in rural municipalities, urban } \\
\text { community hospitals, and physicians in } \\
\text { secondary and tertiary hospitals. }\end{array}$ & $\begin{array}{l}\text { All healthcare professionals have } \\
\text { created their electronic registration } \\
\text { system. Patients often use the systems } \\
\text { to access information, schedule } \\
\text { appointments, send secure messages, } \\
\text { prescriptions or medical records. }\end{array}$ & $\begin{array}{l}\text { (1) Wide role of GPs involved in diagnosis, } \\
\text { treatment and health education, active } \\
\text { and passive surveillance, monitoring, } \\
\text { guidance, and assistance; (2) GPs work in } \\
\text { conjunction with the local neighborhood, } \\
\text { committees and community police for } \\
\text { counseling, screening and monitoring; (3) } \\
\text { WeChat: health screening networks that } \\
\text { provide contact tracking and investigation } \\
\text { of infections sources; (4) Tools such as } \\
\text { migration maps, which use cell phones, } \\
\text { mobile payment applications and social } \\
\text { media to collect real-time data on the } \\
\text { location of people, have allowed Chinese } \\
\text { authorities to track the movement of } \\
\text { people; (5) Capture thermal images of } \\
\text { people in real time, quickly detecting } \\
\text { individuals with fever. }\end{array}$ \\
\hline United States & $\begin{array}{l}\text { There is no universal system, but } \\
\text { assistance with private health } \\
\text { insurance. Low organization of PHC } \\
\text { services. PHC in the United States is } \\
\text { provided by three specialties: family } \\
\text { medicine, general internal medicine, } \\
\text { and general pediatrics. Doctors' main } \\
\text { function is directing the patient to } \\
\text { medical care. It also has nurses and } \\
\text { assistant doctors. There is difficulty } \\
\text { in maintaining the necessary demand } \\
\text { from family and community doctors. }\end{array}$ & $\begin{array}{l}\text { Community health centers are } \\
\text { accessible to needy and uninsured } \\
\text { populations, in addition to quotas } \\
\text { from private providers. In traditional } \\
\text { health insurance plans, visits to primary } \\
\text { care doctors are available for a small } \\
\text { fee. The consultations are directed to } \\
\text { patients with chronic diseases. }\end{array}$ & $\begin{array}{l}\text { (1) Attempt to organize Medicare and } \\
\text { Medicaid; (2) Isolation of contacts and } \\
\text { cases confirmed through laboratory tests; } \\
\text { (3) Urgent and emergency services paid by } \\
\text { users upon the need of use; (4) Support } \\
\text { available from other state/local government } \\
\text { agencies and partner organizations; (5) } \\
\text { Difficulty to implement telemedicine. } \\
\text { Private insurance covered only insured } \\
\text { seniors; (6) Web-based platform HealthMap } \\
\text { provide updated images of COVID-19 cases } \\
\text { and deaths and algorithms allow the effect } \\
\text { of the weather to be incorporated into the } \\
\text { projections. }\end{array}$ \\
\hline Singapore & $\begin{array}{l}\text { The government's health system } \\
\text { is based on the " } 3 \mathrm{M}^{\prime} \text { framework: } \\
\text { Medifund, Medisave, and Medishield. } \\
\text { Primary care is a health system basis } \\
\text { that is provided by government } \\
\text { polyclinics and private GP clinics, } \\
\text { through a network of outpatient } \\
\text { clinics and clinics administered by GPs } \\
\text { supported by Family Medicine Clinics. } \\
\text { The teams of the Community Health } \\
\text { Centers make up the Primary Care } \\
\text { Networks. }\end{array}$ & $\begin{array}{l}\text { In PHC, GPs treat diseases to the most } \\
\text { acute conditions. Standard primary } \\
\text { care services include outpatient } \\
\text { medical treatment and medical follow- } \\
\text { up after hospital discharge, maternal } \\
\text { and child health, immunization, } \\
\text { screening, health education, diagnosis, } \\
\text { and pharmaceutical services. }\end{array}$ & $\begin{array}{l}\text { (1) Free exams and medical care for all } \\
\text { citizens during the outbreak; ( } 2 \text { ) Rigid } \\
\text { contact tracking system with mediated } \\
\text { isolation by criminal charges for those who } \\
\text { disrupt orders; (3) Social distance and fines } \\
\text { payment of up to USD 7,000; (4) Assistance } \\
\text { in public hospitals planned with the } \\
\text { Ministry of Health resources; (5) Monitoring } \\
\text { mediated by IT. UpCode - monitoring trend } \\
\text { of infections, age, gender, etc.; (6) Mobile } \\
\text { application that exchanges Bluetooth short- } \\
\text { distance signals when individuals are close } \\
\text { to each other for } 21 \text { days, if infected, the } \\
\text { government tracks contacts. }\end{array}$ \\
\hline
\end{tabular}

(continues) 
Box 2 (continued)

\begin{tabular}{|c|c|c|c|}
\hline COUNTRY & $\begin{array}{c}\text { HEALTHCARE SYSTEM, PHC } \\
\text { ORGANIZATION AND TEAM } \\
\text { COMPOSITION }\end{array}$ & SERVICES AVAILABLE AT PHC & $\begin{array}{l}\text { FIRST LEVEL RESPONSE TO THE } \\
\text { COVID-19 EPIDEMIC }\end{array}$ \\
\hline Australia & $\begin{array}{c}\text { Mixed coverage, public universal and } \\
\text { private. The gateway occurs in PHC } \\
\text { at home or in community settings, in } \\
\text { general, private, community health } \\
\text { practices. Medicare Locals and Local } \\
\text { Hospital Networks work as local } \\
\text { consumers and providers to develop } \\
\text { integrated, coordinated, and responsive } \\
\text { plans and services. Multi-professional } \\
\text { team. }\end{array}$ & $\begin{array}{l}\text { Health promotion and screening, } \\
\text { disease prevention, early intervention, } \\
\text { treatment, and management. These } \\
\text { services can be targeted to specific } \\
\text { population groups such as the elderly, } \\
\text { maternal and child health, youth health, } \\
\text { people living in rural and remote areas, } \\
\text { Aboriginal and Torres Strait Islander } \\
\text { people, refugees, and people of cultural } \\
\text { or linguistic diversity or with low } \\
\text { socioeconomic status. }\end{array}$ & $\begin{array}{l}\text { (1) The most vulnerable people receive } \\
\text { medical care and primary care advice, } \\
\text { usually through the general practice of } \\
\text { Medicare teams; (2) Online training for } \\
\text { health professionals. Providing advice and } \\
\text { support to the public on social distancing; } \\
\text { substantial investment in mental health } \\
\text { support for all Australians; care for } \\
\text { the elderly, services for the disabled } \\
\text { and hospitals; teleconsultation, triage, } \\
\text { electronic prescription, telemonitoring. }\end{array}$ \\
\hline France & $\begin{array}{l}\text { Universal. GPs work in private practice } \\
\text { or health centers. Nurses provide most } \\
\text { outpatient care at home, especially for } \\
\text { elderly and disabled patients. Multi- } \\
\text { professional approach with the support } \\
\text { of paramedical professionals as } \\
\text { dentists, pharmacists, physiotherapists, } \\
\text { midwives; and outpatient specialists } \\
\text { as pediatricians, gynecologists, } \\
\text { ophthalmologists, and psychiatrists. }\end{array}$ & $\begin{array}{l}\text { Remote and in-person consultation. } \\
\text { The system offers the free choice of } \\
\text { the reference doctors, who may be } \\
\text { a general practitioner, specialist, or } \\
\text { doctor in a public or private hospital, } \\
\text { through an admission regulation } \\
\text { system and referral system. }\end{array}$ & $\begin{array}{l}\text { (1) Functional hierarchy in two levels of } \\
\text { health units; (2) Incentive with doubled the } \\
\text { value of GP consultations; (3) Telemedicine } \\
\text { expansion; (4) Outpatient medicine in the } \\
\text { city and other health units continue to } \\
\text { function normally. }\end{array}$ \\
\hline Canada & $\begin{array}{l}\text { Universal, public and free. PHC is the } \\
\text { first point of contact with the system } \\
\text { in provincial and territorial health care } \\
\text { systems. Teams composed of family } \\
\text { doctors, general practitioners, nurses, } \\
\text { and other professionals who work as } \\
\text { partners. }\end{array}$ & $\begin{array}{l}\text { Governance model based on teams led } \\
\text { by GPs and family doctors with health } \\
\text { team support, promotion, treatment, } \\
\text { diagnosis, basic services, emergency, } \\
\text { and coordination with other levels of } \\
\text { care. }\end{array}$ & $\begin{array}{l}\text { (1) Federal/Provincial/Territorial plan for } \\
\text { response to Public Health for Biological } \\
\text { Events; (2) Active and passive surveillance. } \\
\text { Assess socioeconomic conditions, self- } \\
\text { management capacity, people in university } \\
\text { dormitories, shelters, overcrowded } \\
\text { housing; (3) Daily remote consultation for } \\
\text { patients in home isolation, screening and } \\
\text { remote monitoring. }\end{array}$ \\
\hline Germany & $\begin{array}{l}\text { Universal, a combination of public } \\
\text { and private insurance. There is no } \\
\text { gatekeeping system; it includes all } \\
\text { doctors who treat patients on an } \\
\text { outpatient basis. Patients can directly } \\
\text { access all medical professions, such as } \\
\text { family doctors, specialists, outpatients. } \\
\text { Organized by regional associations of } \\
\text { statutory health insurance doctors. }\end{array}$ & $\begin{array}{l}\text { The regional associations are } \\
\text { responsible for developing a plan } \\
\text { for the location and geographical } \\
\text { distribution of doctors, outpatients, } \\
\text { without a clear distinction from the } \\
\text { doctor's experience or specialty. }\end{array}$ & $\begin{array}{l}\text { (1) Organization of care by GPs, doctors in } \\
\text { partnership with hospitals and local health } \\
\text { departments; (2) Phone lines to answer } \\
\text { questions about the virus at specific times; } \\
\text { (3) Think-tank Digital Health; (4) Smartwatch } \\
\text { app that collects pulse, temperature and } \\
\text { sleep pattern data to detect signs of viral } \\
\text { diseases monitored by the government. }\end{array}$ \\
\hline Italy & $\begin{array}{l}\text { Universal. The GP model and some } \\
\text { outpatient interprofessional teams. } \\
\text { GP is prevalent in some regions and } \\
\text { interprofessional collaboration to } \\
\text { improve accessibility, equity, and } \\
\text { continuity of care. }\end{array}$ & $\begin{array}{l}\text { Based on territorial primary care } \\
\text { units, depending on the region of the } \\
\text { country, besides direct access, phone } \\
\text { consultations are prevalent. }\end{array}$ & $\begin{array}{l}\text { (1) Decentralization of health services and } \\
\text { assistance to the population potentially } \\
\text { affected; (2) Recruitment of health } \\
\text { professionals to the most affected regions } \\
\text { (Lombardia); (3) Solid partnerships between } \\
\text { the public and private sectors have been } \\
\text { institutionalized; (4) Teleconsultation; (5) } \\
\text { Electronic prescription linked to drugstores. }\end{array}$ \\
\hline
\end{tabular}

(continues) 
Box 2 (continued)

\begin{tabular}{|c|c|c|c|}
\hline COUNTRY & $\begin{array}{l}\text { HEALTHCARE SYSTEM, PHC } \\
\text { ORGANIZATION AND TEAM } \\
\text { COMPOSITION }\end{array}$ & SERVICES AVAILABLE AT PHC & $\begin{array}{l}\text { FIRST LEVEL RESPONSE TO THE } \\
\text { COVID-19 EPIDEMIC }\end{array}$ \\
\hline $\begin{array}{l}\text { United } \\
\text { Kingdom }\end{array}$ & $\begin{array}{l}\text { Universal. GP as the gateway of the } \\
\text { healthcare system. The primary care } \\
\text { team including general practitioners, } \\
\text { professional nurses, and management/ } \\
\text { administrative staff, linked to the clinic } \\
\text { or a geographically defined population. }\end{array}$ & $\begin{array}{l}\text { GPs operate through in-person and } \\
\text { remote consultation systems and home } \\
\text { visits (for some specific cases). }\end{array}$ & $\begin{array}{l}\text { (1) Remote triage of all patients by the } \\
\text { healthcare team, considering the suspect } \\
\text { patients, the risk groups, and the large } \\
\text { population; (2) Clinical commissioning } \\
\text { group; (3) Instituted a large-scale } \\
\text { emergency training program to recruit } \\
\text { community workers; (4) Expanded } \\
\text { teleconsultation and telemonitoring. }\end{array}$ \\
\hline Spain & $\begin{array}{l}\text { Universal coverage with access. A } \\
\text { GP is the gateway to the healthcare } \\
\text { system. Operation in primary health } \\
\text { centers with specific regulations } \\
\text { for professional distribution and to } \\
\text { ensure accessibility. Multidisciplinary } \\
\text { team with a nucleus formed by family } \\
\text { and community medicine specialists, } \\
\text { pediatricians, nurses, nursing } \\
\text { assistants, social workers, dentists, and } \\
\text { administrative staff. }\end{array}$ & $\begin{array}{l}\text { Health prevention and promotion, } \\
\text { acute and chronic cases, home care, } \\
\text { and community care activities. Patients } \\
\text { can consult by phone, internet, or } \\
\text { directly at the primary health care } \\
\text { center, and the clinical records are } \\
\text { electronic. }\end{array}$ & $\begin{array}{l}\text { (1) Reorganization of COVID-19 and } \\
\text { not COVID-19 assistance flows in PHC; } \\
\text { (2) Active and passive surveillance; } \\
\text { (3) Multiprofessional team; (4) } \\
\text { Teleconsultation; (5) Creation of monitoring } \\
\text { applications for signs and symptoms. }\end{array}$ \\
\hline Portugal & $\begin{array}{l}\text { Universal with free access. Health } \\
\text { center network composed of small } \\
\text { independent and functional family } \\
\text { health units, providing health care } \\
\text { closer to the citizens. Patients need } \\
\text { a GP referral to access medical } \\
\text { specialties. The family health units are } \\
\text { composed of small multi-professional } \\
\text { teams: } 3 \text { to } 8 \text { family doctors, an } \\
\text { equal number of family nurses, and } \\
\text { administrative professionals. }\end{array}$ & $\begin{array}{l}\text { Health promotion and surveillance, } \\
\text { prevention, diagnosis, and disease } \\
\text { treatment. In different life cycles, } \\
\text { home visits, preventive services, } \\
\text { including immunization and triage for } \\
\text { breast and cervical cancer and other } \\
\text { preventable diseases. Some centers } \\
\text { offer specialized care (mental health, } \\
\text { psychiatry, dermatology, pediatrics, } \\
\text { gynecology and obstetrics, and } \\
\text { surgery). }\end{array}$ & $\begin{array}{l}\text { (1) Attention network reorganization with } \\
\text { physical barriers and assistance flows for ILI } \\
\text { and SARS; (2) Reference services in the PHC } \\
\text { with the Boards of Directors of Local Health } \\
\text { Units; (3) Emergency measures; (4) ADC of } \\
\text { an Emergency Service; (5) Teleconsultation; } \\
\text { (6) Trace-COVID, a support tool for health } \\
\text { professionals. }\end{array}$ \\
\hline Iran & $\begin{array}{l}\text { Mixed system, with public, private } \\
\text { coverage and NGOs. Only primary } \\
\text { health care is included. The team } \\
\text { has up to two doctors, several health } \\
\text { technicians, and “behvarzan" or } \\
\text { community health workers, they are } \\
\text { health professionals with specialized } \\
\text { training in rural health needs. }\end{array}$ & $\begin{array}{l}\text { The team has records for each family } \\
\text { and is responsible for vaccines, records, } \\
\text { medication administration, follow-up } \\
\text { visits to patients, and for identifying } \\
\text { them in neighboring villages, in rural } \\
\text { areas. Women are responsible for } \\
\text { community health in health centers, } \\
\text { through intersectoral actions and } \\
\text { with the collaborative team based } \\
\text { on social determinants of health and } \\
\text { strengthening of local capacity, provide } \\
\text { information to health system managers } \\
\text { and implement actions of assistance } \\
\text { programs the health. }\end{array}$ & $\begin{array}{l}\text { (1) The government initially rejected } \\
\text { quarantine plans in cities and entire areas; } \\
\text { (2) Only individuals with symptoms were } \\
\text { quarantined; (3) Government announced } \\
\text { plans to mobilize 300,000 soldiers and } \\
\text { volunteers in fixed and mobile clinics; (4) } \\
\text { Support from community health workers in } \\
\text { rural areas for active surveillance of users. }\end{array}$ \\
\hline
\end{tabular}

(continues) 
Box 2 (continued)

\begin{tabular}{|c|c|c|c|}
\hline COUNTRY & $\begin{array}{l}\text { HEALTHCARE SYSTEM, PHC } \\
\text { ORGANIZATION AND TEAM } \\
\text { COMPOSITION }\end{array}$ & SERVICES AVAILABLE AT PHC & $\begin{array}{l}\text { FIRST LEVEL RESPONSE TO THE } \\
\text { COVID-19 EPIDEMIC }\end{array}$ \\
\hline Brazil & $\begin{array}{l}\text { Universal and free with the Brazilian } \\
\text { Unified National Health System (SUS), } \\
\text { but with a private sub-system. PHC } \\
\text { is the gateway to the health system, } \\
\text { through family health units and basic } \\
\text { units. Basic teams are made up of } \\
\text { doctors, nurses, nursing technicians, } \\
\text { and community health workers. The } \\
\text { team can comprise oral health and } \\
\text { expanded health nucleus (NASF) with } \\
\text { diversified health professionals. }\end{array}$ & $\begin{array}{l}\text { Health units in areas or territories } \\
\text { delimited to serve a specific number } \\
\text { of families aiming at promotion, } \\
\text { prevention and basic health needs, } \\
\text { with the support of oral health } \\
\text { professionals, NASF, and basic units } \\
\text { with some specialties. }\end{array}$ & $\begin{array}{l}\text { (1) Reorganization of PHC flows for patients } \\
\text { with or without COVID-19; (2) Isolated } \\
\text { people monitoring and telemonitoring; } \\
\text { (3) Active and passive surveillance; (4) } \\
\text { Recruitment through training and online } \\
\text { education of health professionals in activity, } \\
\text { recently graduated, and in the last year of } \\
\text { graduation to cities with higher rates of } \\
\text { cases; (5) Work of community health agents } \\
\text { in remote care with guidance and home } \\
\text { visits to monitor cases. }\end{array}$ \\
\hline New Zealand & $\begin{array}{l}\text { Mixed coverage, public (district councils } \\
\text { and private. PHC refers to professional } \\
\text { health care provided in the community, } \\
\text { in PHOs. PHOs are composed of a GP, } \\
\text { nurse, pharmacist, or another health } \\
\text { professional who works in general } \\
\text { practice. }\end{array}$ & $\begin{array}{l}\text { PHOs ensure the delivery of essential } \\
\text { primary health care services, mainly } \\
\text { through general practices to those } \\
\text { who are enrolled. Care Plus serves } \\
\text { chronic and mental health. PHC centers } \\
\text { prioritize telehealth. }\end{array}$ & $\begin{array}{l}\text { (1) Health and Disability System Response } \\
\text { Plan COVID-19; (2) Services provided } \\
\text { incentives for general practitioners and } \\
\text { other health professionals; (3) TALKING- } \\
\text { COVID-19 Platform; (4) Tele and video } \\
\text { consultation, electronic prescriptions; (5) } \\
\text { Actions in education. }\end{array}$ \\
\hline Iceland & $\begin{array}{l}\text { Universal and free. An integrated } \\
\text { approach to primary health care. The } \\
\text { Primary Care Team organizes and } \\
\text { provides primary health care to the } \\
\text { local population and for supporting } \\
\text { self-care. This is staffed by general } \\
\text { practitioners, nurses, community } \\
\text { nurses, domestic helpers, home care } \\
\text { attendants, occupational therapists, } \\
\text { physiotherapists, speech therapists, } \\
\text { and social workers. }\end{array}$ & $\begin{array}{l}\text { Governance model based on teams led } \\
\text { by general and family doctors and other } \\
\text { health professionals. Telemedicine } \\
\text { support, with shared electronic records, } \\
\text { and an adequate technological support } \\
\text { for all primary care professionals. }\end{array}$ & $\begin{array}{l}\text { (1) Early detection and contact tracking; (2) } \\
\text { Screening of symptomatic patients by the } \\
\text { deCODE genetics company in households } \\
\text { and mobile units parked outside health } \\
\text { clinics; (3) Online training and education for } \\
\text { health professionals; (4) } \\
\text { Early introduction of measures of } \\
\text { total social isolation; (5) Telemedicine, } \\
\text { consultations with video links, British } \\
\text { Columbia COVID-19, and the Support App \& } \\
\text { Self-Assessment Tool applications. }\end{array}$ \\
\hline
\end{tabular}

GP: general practitioners; ILI: Influenza-like illness; NGO: non-governmental organization; PHO: primary health organizations; SARS: severe acute respiratory syndrome.

Source: prepared by the authors.

clinics. Singapore improved methodologies to track contacts 23 , and also created a system that could identify and report in the general practice system, including active case findings among close contacts of affected individuals, including contacts with mild symptoms, to contain clusters and enhanced surveillance to detect individuals affected by COVID-19 early, to allow the containment of the disease 24 .

In Australia, actions against COVID-19 included setting up clear protocols and pandemic response teams, expanding funding to USD 2.4 billion, including payment for telehealth, conducting over 80,000 tests (by March 17, 2020). In PHC, the gateway to the health system, there was the logistics organization, with electronic prescription as a priority to expand access to treatment, contacting and tracking vulnerable groups, especially the elderly, by the multi-professional health teams of Medicare Locals. These teams were supported by Local Hospital Networks, besides keeping the care of other groups by telemedicine, with support from the TALKING-COVID-19 platform 25.

In France, the health system organization is planned to guarantee the timely treatment of patients categorized as COVID-19, based on the functional hierarchy in two levels of health units: first, to 
concentrate available treatment in essential facilities and to ensure that ambulatory medicine and other health units keep working regularly; and second, facilities that have the required resources. Another aspect that is worth mentioning is the low logistical capacity to promote mass testing, due to the limited number of accredited laboratories (only 45 in public facilities). The authorities argued that systematic testing was not necessary. However, on May 5, 2020, France recorded more than 142,903 cases, 28,239 deaths, and 61,728 recoveries, ranking sixth in the number of confirmed cases, overtaking China, where the outbreak began.

In Canada, the first case for COVID-19 was identified on January 25, 202026 imported from China and the response to the pandemic was not perfect until the number of suspected COVID-19 cases in Canada started to increase in mid-February. As of March 22, 2020, it reported a total of 1,563 cases, with 21 deaths, and the different provinces and territories declared a state of emergency. The Canadian Government issued several intervention measures and gradually improved them (https:// www.canada.ca/en/public-health/services/diseases/2019-novel-coronavirus-infection/health-pro fessionals/epidemiological-summary-covid-19-cases.html\#a4, accessed on 10/Apr/2020). Scarabel et al. 27 predicted that if Canada had implemented faster responses in controlling the outbreak through a comprehensive package of public health interventions, it would have contained the number of cases by the end of March.

Canadians are not evenly distributed, but no city is too densely populated, which facilitated later response with the implantation of the Federal/Provincial/Territorial Public Health Response Plan for Biological Events, conducting tests, tracking contacts, limiting the spread and validating results at the local level (https://art-bd.shinyapps.io/covid19canada/https://art-bd.shinyapps.io/covid19canada/, accessed on 14/May/2020). To optimize flows in PHC, an adaptive digital crisis management platform was designed and with the aim of improving the system's response based on the literature and shared between health professionals, policyholders, academia, and the private sector in response to the COVID-19 epidemic 28.

Germany has developed a national plan that has tried to minimize the spread of cases. The complexity of Germany's decentralized health system became evident during the COVID-19 outbreak, together with the national pandemic action plan, each of Germany's states developed its policies and processes. Although the country's authorities initially refuted quarantine, social distancing, or isolation measures, on March 22, 2020, the government announced a national curfew. GPs and hospitals are the gateway to the health system, as there is no gatekeeping system.

Italy was one of the epicenters of the COVID-19 pandemic and since the registration of the first case (Table 1), the National Health Service, which offers universal access to health care, suffered a great pressure due to the growth of cases, especially in the northern region of the country, where the system came close to a collapse 29 . Some emergency measures were taken: first, the strengthening of national coordination. Second, the capacitation and financing of health systems were made more flexible to cover exceptional emergencies. Third, strong partnerships were institutionalized between the public and private sectors in response to emergencies. The remote telemedicine service for isolated or quarantined people was also expanded and drugstores were connected to the telemedicine network to reduce the need to present a medical prescription for obtaining drugs during the pandemic 29.

In the United Kingdom, PHC has changed dramatically, with new ways of working for clinical and administrative staff. The operational model for general practice in the epidemic included the remote triage of all patients by a health team, considering suspected cases, risk groups, and the large population. The most relevant local flows have been regionally discussed with Clinical Commissioning Group (CCG). Thus, the team can access the computers' general practice systems from other locations, facilitating remote consultations, data management, and health information ${ }^{30}$. During the health emergency they maintained the organizational arrangements, such as home visits restricted to the groups at risk, presential and/or remote consultation supported by trained community workers and supervised by resident doctors 31 .

Spain provided flows and isolation areas for patients who met the criteria for coronavirus disease, which included active and passive case surveillance, both in person and by telemedicine. Health professionals interact closely with patients and their families based on an integrated approach that allowed them to draw up specific treatment plans for the patients and share with them the responsibility for decisions about their health. 
Portugal was one of the European countries that presented a decrease of COVID-19 new cases. The health system's preparation for the pandemic mitigation phase included the health services' organization with the placement of physical barriers to reduce exposure to SARS-CoV-2 with Specific circuits/flows created for respiratory patient / suspect and/or confirmed cases of COVID-19. PHC reference services were created with the Local Health Units (LHU) Management Boards and Executive Directors to ensure the creation of at least one area dedicated to COVID-19 in each unit. In these areas, the service was staggered by remotely scheduling the telemedicine service, stratifying those indicated for evaluation in the PHC.

In Iran, the public coverage in the country includes only PHC with low increased awareness of preventive methods in controlling COVID-19 and in the United States there was an expansion of telemedicine by health insurance 25 .

In Brazil, one of the largest public health systems in the world and the only one to guarantee integral and free assistance to the entire population, has assumed a fundamental role in containing the disease 32. In the beginning of February 2020, even without having confirmed cases of COVID-19, the Brazilian Ministry of Health triggered the National Public Health Emergency Response Plan and implemented the Public Health Emergency Operations Center for the new Coronavirus.

The Brazilian Ministry of Health published several technical documents guiding the restructuring of practices within the scope of the Family Health Strategy (FHS) and strengthened a universal Epidemiological Surveillance system, to serve the entire health care network considering the particularities of the regional context and local. Recently, the system's underfunding and austerity policies have reduced responsiveness of the PHC 32. And the aggravation and urgency presented by the COVID-19 pandemic showed the concentration of resources in specific regions and large cities.

In addition, the organizational heterogeneity of the local systems was evidenced, which adopted different operational flows according to the local particularities: difficulties in coordination between surveillance and health care actions in the PHC; absence of federative coordination; difficulties in creating regional models to combat the pandemic; limited use of the potential and capillarity of primary care and the family and community health strategy, in order to increase the sense and engagement of the community and the absence of real-time health information systems (electronic medical records).

Even in this context, some experiences 32,33 report strategies adopted by municipalities in response to the COVID-19 pandemic, such as changes in the health work process with the incorporation of communication technologies that have saved time for the reorganization of PHC and the support of the Expanded Health Center of Family and Primary Care (NASF), in the call center and matrix support with PHC teams 32. Even without safe working conditions, the professionals of the FHS have sought to expand COVID-19's coping strategies including monitoring patients with remote surveillance of the symptomatic people's clinical picture (in some municipalities) and the action of Community Health Agents, in supporting activities in family health units, in the search and tracking of respiratory symptoms in the territory, and health education articulated to the population through community surveillance 34,35 .

New Zealand early established a structure to prepare and manage the national response, with home-based care for the elderly and strategies for tracking and counseling patients with mild cases in home isolation. To provide continuous access, PHC has expanded the notification and guidance system for remote consultations according to the severity of cases. Also, the government offers financial incentives for general practitioners and other health professionals for in-person (when unable to use telemedicine) and remote services during the epidemic to ensure free, timely, and proper access to users. The country has also adopted isolation for the entire population at the beginning of the pandemic and extensive testing.

In Iceland, many tests were carried out per capita, including general population triage, to determine the spread of the virus in the community. As there is no private health system, medical assistance is free and universal. A multi-professional team was in charge of the PHC organization to control the disease. Unlike most other countries, Iceland has launched widespread testing of asymptomatic individuals. 


\section{Discussion}

Worldwide, all health systems include primary care. Universal public health systems, anchored in a robust, resolutive, comprehensive, social, and culturally accessible PHC, are one of the pillars of a society that respects citizens' rights, although the scope varies substantially between countries 16,17,28.

There are stark differences between the healthcare systems which have caused them to respond to public health crises in markedly different ways. This is of importance to public health organizations because it serves as a guideline for identifying efficacious policies.

Among the countries analyzed, those with relatively effective primary care were, for example, Brazil, Portugal, Canada, Spain, and the United Kingdom. However, despite the fact that these countries have primary care policies and regulations in place, not all have had quick responses to address the pandemic. There is a variation in the strength of primary care indicating a discrepancy in the responsibility given to the service by national political initiatives and also in the necessary investments, like the future lack of specialized labor, general practitioners, and other professionals, as well as improving its primary care information infrastructure to facilitate its performance management.

In the COVID-19 pandemic, the different National Health Services in all countries are under enormous pressure. Despite the variations in the duration, size, and stage of PHC organization, the situation in Europe and in the countries of North America is that almost all countries in these areas are currently in the process of mitigating community transmission. However, countries like China, since the outbreak of the severe acute respiratory syndrome (SARS), reorganized the public health system with the inclusion of a Center for Disease Control and Prevention (China CDC) in 2002, integrating public health surveillance, which makes it possible to quickly analyze data from centers linked to the National Program of Basic Public Health Services for decision making by health management 36 .

Italy, Spain, and France occupied the first three positions in number of deaths, forcing all European countries to impose measures to contain the spread of the virus. Although they vary considerably, the mitigation roadmap has a central element in common: the variation in the general strength of primary care seems to refer to different degrees of governance of primary care and the results achieved in the (primary) health system and the response was vulnerable to poor service coordination 30.

Countries that have a primary care governance system such as Singapore, Iceland, Australia, and New Zealand have set explicit targets linked to policies on equity in access to these services, ensuring universal financial coverage through a publicly responsible body, with faster and more comprehensive responses. Germany, Iran, Australia, China, Singapore, and New Zealand have universal public and private systems, which means they are decentralized to the regional level. Germany does not have a gatekeeping system ${ }^{27}$. PHC is responsible for the health center's strategic and operational management for referrals or regional distinctions for assistance coverage or co-payments with registration systems and electronic referral 30,37,38,39,40.

We would also like to emphasize countries that have had recent epidemic experiences, such as Singapore, already had structures and systems organized since the 2003 SARS experience and the strategy of "testing, tracking, and isolating" were arguably the main factors for flattening the epidemic curve at the beginning of the pandemic 41 . This has provided healthcare systems with the evolution of their clinical operations and the leverage of their academic culture, with advances in bench research, global health, epidemiology, clinical research, IT, and specialists that have driven faster scientifically based responses to coping with the COVID-19.

In most countries, important governance functions (for example, priority setting, and supply planning) have been decentralized to regional and local authorities. The degree and standards allow for geographic variation of practices, and according to local priorities, they had greater difficulty in establishing responses, as happened in the United Kingdom, France, Italy. Countries like Canada, although decentralization can increase the response capacity of primary care at regional or local level, there was a risk of interregional inequalities in access, financing, quality of care, and, ultimately, health, with slow response in facing the pandemic.

As the United Kingdom experience shows, this can be difficult. There was a clear lack in the central direction or clinical care model for CCGs at the National Health Service 42,43,44. It is worth mentioning that in Italy, organizational arrangements vary between regions including organizational models based on interprofessional integration 40 . 
Countries with primary care integration in the health system show care continuity and efficiency and the provided services scope can influence the access to support and impact responses to the pandemic. This process occurs through interdisciplinary collaboration between primary and secondary care promoted by government integration programs or by legislation 43 , as well as Spain and Portugal 28,29.

In Brazil, although the Unified National Health System (SUS), and the FHS 4,30 has not been the gateway to COVID-19's mitigation strategies. Few or almost no management initiatives have been implemented, and it is research, and the increasing number of networks of researchers and universities, that guide some decisions.

At the same time, territorial inequalities point out that not all municipalities, and especially the health regions constituted, have professionals, resources, or financing and management capacity compatible with the needs to implement actions to combat the pandemic. Isolated actions and/or without regional, state, and federal support and coordination can result in an increase in inequalities in supply and access to health services during the pandemic.

Some municipalities and states sought to reverse this initial suppression of PHC, with a view to promoting a coordinated response through the articulation and integration of the actors involved and expand efforts to build the analysis of data and information to support the managers' decision making and sharing with other institutions started to monitor the data collected by the states of the country, support data transparency, and new strategies to guarantee a universal and equitable health system 45 .

In most countries, the development and use of information and communication technologies (ICTs) in primary care contributed to the responses to the pandemic, considering each particularity, and can be considered one of several important characteristics for reducing the incidence of COVID-19 and mortality 9,38,39,40. It constitutes one of the legacies of the pandemic and a differential to expand remote health care 16 . However, digital health initiatives can widen socioeconomic inequalities and contribute to health disparities, as its use was disproportionately greater in high-income areas than in low- and middle-income areas (82\% in Europe vs. 28\% in Africa) 37,42,46.

\section{Main lessons learned}

The coverage and organization of the strategies were not the same in different countries. The implementation of these actions was guided by the local characteristics of disease transmission, demography and organization of public health services, as well as by the capacity and financing of the health system, especially within the PHC. This is worth reflecting, in order to subsidize action planning in countries with a high incidence of cases by other nations 29,30,42.

However, there are limitations that need to be noted: populations with different age structures, which should be taken into account when calculating the standardization of mortality rates for the purpose of comparing the measures, as well as the presence of comorbidities related to the worsening of COVID-19, which also influences the mortality rate. Studies show sociodemographic differences, according to age group stratification and population's health conditions, such as obesity, diabetes, hypertension, and in conditions that affect immunity, will have higher mortality rates and, consequently, higher rates of lethality 20,22,47. Regarding the use of COVID-19 lethality and mortality indicators and the comparison between countries, due to differences in the policy definitions, can be a source of bias 22. Thus, due to the wide variation of these indicators, although mentioned in this study, priority was given to analyzing the response of the health system, in particular of PHC 19.

Furthermore, the scope of this study is descriptive and did not aim to include a formal statistic comparison, as it would require the use of statistical models and an appropriate analytical consideration of variables, and indicators of the socio-cultural (including educational systems), political, and structural features of each country. This perspective deserves to be better investigated in future studies.

Finally, the main lesson learned was that an efficient PHC, with actions guided by integrality, longitudinality, and community orientation and aligned with the population's health needs, is the basis for any intervention proposal 44 . Therefore, it must consider the capacity or experience obtained in each country, given the emerging demands of health systems, especially in a pandemic condition. 


\section{Contributors}

All authors contributed equally to the conception, design, acquisition, analysis, and data interpretation in the elaboration of the work.

\section{Additional informations}

ORCID: Nilia Maria de Brito Lima Prado (00000001-8243-5662); Thais Regis Aranha Rossi (00000002-2561-088X); Sônia Cristina Lima Chaves (0000-0002-1476-8649); Sandra Garrido de Barros (0000-0002-8255-1230); Laio Magno (0000-00033752-0782); Hebert Luan Pereira Campos dos Santos (0000-0003-2722-7945); Adriano Maia dos Santos (0000-0001-9718-1562).

\section{Acknowledgments}

The authors would like to thank for translation of this article by members of the voluntary translation of informative materials related to COVID-19 project, offered by NUPEL/UFBA and supervised by professors M. Daniel Vasconcelos, Dr. Feibriss Henrique Meneghelli Cassilhas, Dr. Lucielen Porfírio and Dr. Monique Pfau. Translators: Fernanda Costa and Simone Salles.

\section{References}

1. Starfield B, Shi L, Macinko J. Contribution of primary care to health systems and health. Milbank Q 2005; 83:457-502.

2. Organização Pan-Americana da Saúde. Renovação da atenção primária em saúde nas Américas. Documento de posicionamento da Organização Pan-Americana da Saúde/Organização Mundial da Saúde (OPAS/OMS). Washington DC: Organização Pan-Americana da Saúde; 2007.

3. Lima LD. Crisis y neoliberalismo: desafíos y alternativas políticas para la construcción de sistemas universales de salud en América Latina. Cad Saúde Pública 2017; 33 Suppl 2:e00047517.

4. Fausto MCR, Rizzoto MLF, Giovanella L, Seidl $\mathrm{H}$, Bousquat A, Almeida PF, et al. O futuro da atenção primária à saúde no Brasil. Saúde Debate 2018; 42:12-4.

5. Giovanella L, Mendoza-Ruiz A, Pilar ACA, Rosa MC, Martins GB, Santos IS, et al. Universal health system and universal health coverage: assumptions and strategies. Ciênc Saúde Colet 2018; 23:1763-76.

6. Liu Y, Gayle AA, Wilder-Smith A, Rocklöv J. The reproductive number of COVID-19 is higher compared to SARS coronavirus. J Travel Med 2020; $27:$ taaa021.

7. Fauci AS, Lane HC, Redfield RR. Covid-19 navigating the uncharted. N Engl J Med 2020; 382:1268-9.

8. Walker PGT, Whittaker C, Watson O, Baguelin $\mathrm{M}$, Ainslie K, Bhatia S, et al. The global impact of COVID-19 and strategies for mitigation and suppression. London: Imperial College London; 2020. https://spiral.imperial.ac.uk:8443/ handle/10044/1/77735.

9. Anderson RM, Heesterbeek H, Klinkenberg D, Hollingsworth TD. How will country-based mitigation measures influence the course of the COVID-19 epidemic? Lancet 2020; 395:931-4

10. World Health Organization. Infection prevention and control during health care when COVID-19 is suspected. Interim guidance. https://www.who.int/publicationsdetail/ infection-prevention-and-control-duringhealth-care-when-novel-coronavirus-(ncov)infection-is-suspected-20200125 (accessed on 19/Mar/2020).

11. Ferguson N, Laydon D, Nedjati Gilani G, Imai N, Ainslie K, Baguelin M, et al. Impact of non-pharmaceutical interventions (NPIs) to reduce COVID-19 mortality and healthcare demand. London: Imperial College London; 2020. https://spiral.imperial.ac.uk:8443/han dle/10044/1/77482. 
12. Santos JV, Fachin P. Como se dará a evolução de Covid-19 na população que vive em condições precárias? Entrevista especial com Guilherme Werneck. IHU On-Line 2020; 27 mar. http://www.ihu.unisinos.br/159-noticias/ entrevistas/597542-como-se-dara-a-evolu cao-de-covid-19-na-populacao-que-vive-emcondicoes-precarias-entrevista-especial-comguilherme-werneck-2.

13. Dunlop C, Howe A, Li D, Allen LN. The coronavirus outbreak: the central role of primary care in emergency preparedness and response. BJGP Open 2020; 4:bjgpopen20X101041.

14. Sarti TD, Lazarini WS, Fontenelle LF, Coelho AP. What is the role of primary health care in the COVID-19 pandemic? Epidemiol Serv Saúde 2020; 29:e2020166.

15. Turci M, Holliday J, Oliveira N. A vigilância epidemiológica diante do Sars-Cov-2: desafios para o SUS e a atenção primária à saúde. APS em Revista 2020; 2:44-55.

16. Bitton A, Fifield J, Ratcliffe H, Karlage A, Wang $\mathrm{H}$, Veillard JH, et al. Primary healthcare system performance in low-income and middleincome countries: a scoping review of the evidence from 2010 to 2017. BMJ Glob Health 2019; 4:e001551.

17. Hone T, Macinko J, Millett C. Revisiting AlmaAta: what is the role of primary health care in achieving the Sustainable Development Goals? Lancet 2018; 392:1461-72.

18. Haggerty J, Burge F, Lévesque JF, Gass D, Pineault R, Beaulieu MD, et al. Operational definitions of attributes of primary health care: consensus among Canadian experts. Ann Fam Med 2007; 5:336-44.

19. Brahma D, Chakraborty S, Menokee A. The early days of a global pandemic: a timeline for the spread of COVID-19 and government interventions. https://www.brookings. edu/2020/04/02/the-early-days-of-a-globalpandemic-a-timeline-of-covid-19-spreadand-government-interventions/ (accessed on 22/May/2020).

20. Goldstein JR, Lee RD. Demographic perspectives on the mortality of COVID-19 and other epidemics. Proc Natl Acad Sci U S A 2020; 117:22035-41.

21. Liang L, Tseng C, Ho HJ, Wu CY. Covid-19 mortality is negatively associated with test number and government effectiveness. Sci Rep 2020; 10:12567.

22. Chaudhry R, Dranitsaris G, Mubashir T, Bartoszko J, Riazi S. A country level analysis measuring the impact of government actions, country preparedness and socioeconomic factors on COVID-19 mortality and related health outcomes. EClinicalMedicine 2020; 25:100464.

23. Wong JEL, Leo YS, Tan CC. COVID-19 in Singapore - current experience: critical global issues that require attention and action. JAMA 2020; 323:1243-4.
24. Paul G. ZTE and China Telecom enabled the first remote diagnosis of coronavirus using a 5G telehealth system. Business Insider 2020; 28 jan. https://www.businessinsider.com/ztechina-telecom-build-5g-telehealth-systemfor-coronavirus-2020-1?IR=T.

25. Centers for Disease Control and Prevention. Implementation of mitigation strategies for communities with local COVID-19 transmission. https://www.cdc.gov/coronavirus/2019ncov/downloads/community-mitigationstrategy.pdf (accessed on 24/Apr/2020).

26. Marchand-Senécal X, Kozak R, Mubareka S, Salt N, Gubbay JB, Eshaghi A, et al. Diagnosis and management of first case of COVID-19 in Canada: lessons applied from SARS-CoV-1. Clin Infect Dis 2020; (Online ahead of print).

27. Scarabel F, Pellis L, Bragazzi NL, Wu J. Canada needs to rapidly increase public health interventions for its COVID-19 mitigation strategies. Infect Dis Model 2020; 5:316-22.

28. Kuhlmann E, Batenburg R, Dussault G. A people-centred health workforce in Europe: how to make it happen? Health Policy 2018; 122:1053-4.

29. Lau H, Khosrawipour V, Kocbach P, Mikolajczyk A, Schubert J, Bania J, et al. The positive impact of lockdown in Wuhan on containing the COVID-19 outbreak in China. J Travel Med 2020; 27:taaa037.

30. Macinko J, Dourado I, Aquino R, Bonolo PF, Lima-Costa MF, Medina MG, et al. Major expansion of primary care in Brazil linked to decline in unnecessary hospitalization. Health Aff (Millwood) 2010; 29:2149-60.

31. NHS England. General practice in the context of coronavirus (COVID-19). https://www. england.nhs.uk/coronavirus/primary-care/ general-practice/standard-operating-proce dures/ (accessed on 24/Apr/2020).

32. Guimarães FG, Carvalho TML, Bernardes RM, Pinto JM. A organização da atenção primária à saúde de Belo Horizonte no enfrentamento da pandemia COVID-19: relato de experiência. APS em Revista 2020; 2:74-82.

33. Silveira JPM, Zonta R. Experiência de reorganização da APS para o enfrentamento da COVID-19 em Florianópolis. APS em Revista 2020; 2:91-6.

34. Maciel FBM, Santos HLPC, Carneiro RAS, Souza EA, Prado NMBL, Teixeira CFS. Agente comunitário de saúde: reflexões sobre o processo de trabalho em saúde em tempos de pandemia de Covid-19. Ciênc Saúde Colet 2020; 25 Suppl 2:4185-95.

35. Latgé PK, Araujo DN, Silva Júnior AG. Comunicação, educação e vigilância popular em saúde em tempos de COVID-19: a experiência das comunidades de Niterói, RJ. APS em Revista 2020; 2:122-7. 
36. Li X, Krumholz HM, Yip W, Cheng KK, De Maeseneer J, Meng Q, et al. Quality of primary health care in China: challenges and recommendations. Lancet 2020; 395:1802-12.

37. Whitelaw S, Mamas MA, Topol E, Van Spall HGC. Applications of digital technology in the planning and response to the COVID-19 pandemic. Lancet Digit Health 2020; 2:e435-40.

38. Adlhoch C, Baka A, Ciotti M, Gomes J, Kinsman J, Leitmeyer $\mathrm{K}$, et al. Considerations related to social distance measures in response to the COVID-19 epidemic. https://www. ecdc.europa.eu/en/publications-data/consid erations-relating-social-distancing-measuresresponse-covid-19-second (accessed on 20/ May/2020).

39. Xia W, Liao J, Li C, Li Y, Qian X, Sun X, et al. Transmission of corona virus disease 2019 during the incubation period may lead to a quarantine loophole. medRxiv 2020; 8 mar. https://www.medrxiv.org/content/10.1101/2 020.03.06.20031955v1.

40. Hollander JE, Carr BG. Virtually perfect? Telemedicine for Covid-19. N Engl J Med 2020; 382:1679-81.

41. Heymann DL, Shindo N. COVID-19: what is next for public health? Lancet 2020; 395:542-5.
42. Greenhalgh T, Wherton J, Shaw S, Morrison C. Video consultations for covid-19. BMJ 2020; 368:m998.

43. Dorsey ER, Topol EJ. Telemedicine 2020 and the next decade. Lancet 2020; 395:859.

44. Minué SL. La pandemia COVID-19: lo que hemos aprendido hasta ahora desde España. Experiências no manejo da COVID-19. APS em Revista 2020; 2:28-32.

45. Requia WJ, Kondo EK, Adams MD, Gold DR, Struchiner CJ. Risk of the Brazilian health care system over 5572 municipalities to exceed health care capacity due to the 2019 novel coronavirus (COVID-19). Sci Total Environ 2020; 730:139144.

46. Ortega G, Rodriguez JA, Maurerc LR, Wittd EE, Perez N, Reicha A, et al. Telemedicine, COVID-19, and disparities: policy implications. Political Health and Technology 2020; 2:1-4.

47. Onder G, Rezza G, Brusaferro S. Case-fatality rate and characteristics of patients dying in relation to COVID-19 in Italy. JAMA 2020; 323:1775-6. 


\section{Resumo}

O estudo examina a organização da atenção primária em saúde (APS) na resposta à epidemia da COVID-19. É um estudo descritivo com base em análise documental das respostas nacionais à pandemia do novo coronavirus, com ênfase na APS. Em distintos paises, houve diferentes formas de organização e impactos das estratégias, uma vez que realizaram ações de acordo com as características locais da transmissão da doença, demografia, organização dos serviços de saúde pública e capacidade e financiamento do sistema de saúde, principalmente na APS. Uma mudança significativa durante a pandemia tem sido o aumento nas consultas telefônicas e por videoconferência, incorporando a tecnologia de informação em saúde. Uma APS eficiente, orientada por ações essenciais, alcança resultados mais adequados. Além disso, a capacidade acumulada ou experiência de cada país faz a diferença ao enfrentar as demandas emergentes sobre diferentes sistemas de saúde.

Atenção Primária à Saúde; Infecções por

Coronavírus; Política de Saúde;

Sistemas de Saúde

\section{Resumen}

Este estudio examina la organización de la atención primaria en salud (APS), como respuesta a la epidemia de COVID-19. Es un estudio descriptivo basado en el análisis documental de las respuestas de países a la pandemia de coronavirus con énfasis en la APS. En varios países, ha habido diferentes organizaciones e impactos de estrategias, puesto que han llevado a cabo acciones según las características locales de transmisión de la enfermedad, demografía, organización de los servicios públicos de salud, y capacidad del sistema de salud, así como financiación, especialmente en la APS. Un cambio significativo durante la pandemia ha sido el incremento de las consultas por teléfono y vídeo, incorporando tecnología para la información en salud. Una APS eficiente, guiado por acciones básicas, consigue resultados más adecuados. Asimismo, la capacidad acumulativa de cada país o la experiencia es lo que marca la diferencia, enfrentándose a las demandas que surgen en diferentes sistemas de salud.

Atención Primaria de Salud; Infecciones por Coronavirus; Política de Salud; Sistemas de Salud
Submitted on 29/Jun/2020

Final version resubmitted on 27/Aug/2020

Approved on 04/Sep/2020 